\title{
Corporate Sustainability: Necessary Aspects for the Site Selection Process for an Industrial Company
}

\author{
Christian Schneider ${ }^{1}$ \\ ${ }^{1}$ Slovak University of Technology in Bratislava, Institute of Industrial Engineering and Management, Trnava, \\ Slovak Republic \\ Correspondence: Christian Schneider, Slovak University of Technology in Bratislava, Institute of Industrial \\ Engineering and Management, Trnava, Slovak Republic. Tel: 49-178-503-3404. E-mail: \\ Christian.schneider@zf.com
}

Received: December 13, 2014 Accepted: February 3, $2015 \quad$ Online Published: February 20, 2015

doi:10.5539/jms.v5n1p186 URL: http://dx.doi.org/10.5539/jms.v5n1p186

\begin{abstract}
Today the in scholarship used sets of selection criteria for side selection do not include the within industry very important new criteria "Corporate Sustainability" in the meaning of "business approach with embracing opportunities and managing risks deriving from economic, environmental and social developments" or if in few aspects, not in the necessary weight. Within this article it will be described shortly which doctrines are leading today in science, why compliance conformance has high importance for global enterprises and why scientific as well as operational sets of selection criteria for global enterprises will have to be completed with aspects of compliance.
\end{abstract}

Keywords: sustainability, site selection, criteria

\section{Introduction}

The Global economy is currently facing substantial challenges. Global GDP growth is below long term trend and there is a noticeable slowdown of industrial production in most European countries. Africa, Latin America and especially Asia have already become the engine of global growth and experts are forecasting that the worldwide future growth will mainly take place in Asia. An optimized Global Foot Print of production sites, covering existing and growing markets, is one of the major success factors for global enterprises to make the changes in global economic growth beneficial for their own profitable growth. The selection of new sites as well as regular checking of existing sites with a standardized set of criteria in front of the company strategy leads to this optimized Global Foot Print. But today used sets of selection criteria in scholarship do not include the within industry very important new criteria "Corporate Sustainability" in the meaning of "business approach with embracing opportunities and managing risks deriving from economic, environmental and social developments". Own experiences as a Manager in M\&A-/ Corporate Development of a globally leading automotive supplier, discussions and Interviews with experts from other global enterprises as well as scientific research leaded to the necessity to point out the growing importance of Corporate Sustainability and that scientific as well as operational sets of selection criteria for side selection will have to be completed with aspects of Corporate Sustainability.

\section{Results}

\subsection{Industrial Localization Theory and Todays Doctrines}

In scientific literature there are already existing several industrial location theories and doctrines including the in each case connected classification and sets of criteria for site selection.

Classical- and Neo-Classical theory is strongly focusing on cost for transport and labor as well as advantages of agglomeration in sense of local nearness but not on behavioristic, mental and cultural aspects. On the other hand Behavioristic Theories consider behavioristic, mental and cultural aspects but not the monetary and cost effects. The New Economical Geography again concentrates on reduction of transport costs with the effects on local distribution pattern of economically activities but is configured for economic-political appliance and not for the use within industrial enterprises. Only the new publications from for example Grabow and Thiessen, subdivide location criteria into Hard and Soft facts in meaning of criteria which can be easily measured, quantified in 
money and are having direct influence on cost and qualitative criteria which are having indirect effects on the company and their employees. But those authors do not reflect in appropriate way the today very important new criteria within industry "Corporate Sustainability" to secure embracement of opportunities and managing risks deriving from economic, environmental and social developments for new sites.

This leads to the need to develop a holistic system of criteria for site selection and evaluation, including Hard and Soft facts. Creating this holistic system including as well as integrating the main aspects of the different doctrines and enriching them with new criteria out of practical life will not only allow a scientific value added. It shall enable global enterprises to do a well-founded and practice oriented comparison between different locations and sites and reduce the risk of baseless, irreproducible or suboptimal decisions regarding sites. The special focus of this article will be the answer, why Corporate Sustainability has to be added and followed within side selection processes.

\subsection{The Importance of Corporate Sustainability in Business Life}

"Corporate Sustainability is a business approach that creates long-term shareholder value by embracing opportunities and managing risks deriving from economic, environmental and social developments."

Sustainability is not a really new subject in economical content. It was already used 300 years ago in 1713 from Hans Carl von Carlowitz with regard to forestry in the meaning of sustainable use of the resource wood.

In the $20^{\text {st }}$ century the discussion rose in a new understanding with the Brundtland Commission of the United Nations in 1987. Sustainability was defined newly but in a general way: "sustainable development is development that meets the needs of the present without compromising the ability of future generations to meet their own needs."

In 1992 the United Nations Conference on Environment and Development enlarged and fixed sustainability with international agreements with respect to the interests of integrity of the global environmental and developmental system by proclaiming 27 principles. These principles intended to rule the future sustainable development around the world.

With the 2005 World Summit on Social Development it was noted that Sustainable Development requires the reconciliation of

1. environmental,

2. social equity and

3. economic demands - todays' "three pillars" of sustainability (or the 3 Es)

From then on Sustainability and Sustainability Development focused on

- Politics

- Society,

- $\quad$ science and

- $\quad$ economical enterprises. ${ }^{\text {comp. note }[24]}$

Today, 25 years after the Brundtland Commission of the United Nations in 1987, the awareness of Corporate Sustainability has truly reached politics, society, science and business.

Politic is following sustainability by enhanced environmental and social legislation. Science started to implement professorship and degree programs for corporate sustainability management, as for example the Friedrich-Alexander University, Erlangen-Nürnberg in Germany.

Society and non-governmental organizations are caring much more about climatic change, $\mathrm{CO}^{2}$-balance, preserve energy consumption as well as human rights and are asking for excessed transparency:

And Business is following Sustainability as Corporate Sustainability intensively by multible reasons. On the one hand there is the rising pressure regarding sustainability caused by demands from politic, public and other external groups of stakeholders such as legislation or advertence of media. With Sustainability companies are intending the legitimation of their acting, their products and services by dealing with sustainability. On the other hand customer demands, request from investors, rating agencies and the behavior of competitors can place market impulsions to follow sustainability.

This means that companies are following sustainability by

- defensive reasons, such as following legislation, reduction of risks and cost and 
- offensive strategies to realize chances such as increasing reputation to be an attractive employer for potential talents, to realize higher sales or entering new markets and business models.

Summing up there are defensive and offensive reasons to follow sustainability which can be clustered into three types of group of interests, internal, governmental/society and market.

Within the last years the main important role regarding realization of sustainability was assigned to the Business-Sector, so called Corporate Sustainability because sitting in the driver seat of globalization, production and development. Many enterprises are aware of their environmental, social equity and economic responsibility. Corporate Sustainability and the transparency concerning sustainable acting has been realized as a major long term success factor and companies are more and more measured from outside as well measuring themselves regarding Sustainability.

Therefor the Top-Management of worldwide 7000 organizations and thereof more than 5000 global companies including almost all enterprise, listed in DAX- or Dow Jones, has signed the United Nations Global Compact voluntarily. With this they obligate their organizations to obey the 10 principles of the Global Compact including an annual Report presenting that the principles are followed.

The 10 principles are:

"Human Rights

Principle 1: Businesses should support and respect the protection of internationally proclaimed human rights;

Principle 2: make sure that they are not complicit in human rights abuses.Labour Standards

Principle 3: Businesses should uphold the freedom of association and the effective recognition of the right to collective bargaining;

Principle 4: the elimination of all forms of forced and compulsory labour;

Principle 5: the effective abolition of child labour;

Principle 6: the elimination of discrimination in respect of employment and occupation.

Environment

Principle 7: Businesses should support a precautionary approach to environmental challenges;

Principle 8: undertake initiatives to promote greater environmental responsibility;

Principle 9: encourage the development and diffusion of environmentally friendly technologies.

Anti-Corruption

Principle 10: Businesses should work against all forms of corruption, including extortion and bribery.”

Result of a sustainability study of the Center for Sustainability Management e.V., Germany, with 463 companies in 2012 is that the main reasons for Companies to follow corporate sustainability are:

1. Efficiency

2. Control of risks

3. Reputation

4. Job satisfaction

5. Costs

6. Turnover and

7. Innovation

Another finding is that $94 \%$ of the participating enterprises are stating that the success and acceptance of Corporate Sustainability is depending on the integration into the core strategy and organization of enterprises. This means an enlargement of the above mentioned aspects to be followed

1. environmental requirements

2. social equity and

3. economic demands - by the aspect of

4. Integration into core strategy and organization 
It also can be seen within this study that Corporate Sustainability is put on weight by the fact that Corporate Sustainability department is mostly reporting to the Board of Management directly. Other cases are reflecting the importance of information and transparency regarding Sustainability to all groups of Stakeholders due to the fact that Corporate Sustainability is part of the Public Relation / Communication organization.

In the past, Corporate Sustainability was mainly focused on sustainability of the own, individual company. Within latest publications it is consequently shown, that the focus of Corporate Sustainability cannot be caped on the own organization only. It has to be enlarged to the entire chain of value added including supplier base.

This new aspect of integrating the value chain together with above mentioned demand of integration into core strategy and organization leads to the list of aspects to be followed, shown in the table following:

\begin{tabular}{|c|c|c|}
\hline \multicolumn{3}{|c|}{ Thematic Aspects } \\
\hline Environment & Social & $\begin{array}{l}\text { Economic \& } \\
\text { Governance }\end{array}$ \\
\hline $\begin{array}{l}\text { - Environment } \\
\text { protection } \\
\text { - climate protection } \\
\text { - Efficient use of } \\
\text { materials, energy } \\
\text { and water } \\
\text { - hazardous } \\
\text { production } \\
\text { material } \\
\text { - Safety in } \\
\text { equipment and } \\
\text { transportation }\end{array}$ & $\begin{array}{l}\text { - Social standards } \\
\text { and labor } \\
\text { conditions incl. } \\
\text { human rights, } \\
\text { minimum wage, } \\
\text { child- and forced } \\
\text { labor as well as } \\
\text { discrimination } \\
\text { - occupational } \\
\text { health and safety } \\
\text { - Influence on social } \\
\text { periphery }\end{array}$ & $\begin{array}{l}\text { - Responsibility of } \\
\text { Management incl. } \\
\text { integration into } \\
\text { core strategy } \\
\text { - Commitment of } \\
\text { Management } \\
\text { regarding } \\
\text { sustainability } \\
\text { - working against all } \\
\text { forms of } \\
\text { corruption }\end{array}$ \\
\hline
\end{tabular}

\begin{tabular}{|c|c|}
\hline \multicolumn{2}{|c|}{ Process Aspects } \\
\hline Management & $\begin{array}{l}\text { Monitoring \& } \\
\text { Transparence }\end{array}$ \\
\hline $\begin{array}{l}\text { - Managements } \\
\text { systems, Norms } \\
\text { and guidelines } \\
\text { supporting } \\
\text { sustainability } \\
\text { - Escalation- and } \\
\text { Development incl. } \\
\text { reporting and } \\
\text { measurements } \\
\text { - Supplier selection } \\
\text { and development } \\
\text { concerning } \\
\text { sustainability }\end{array}$ & $\begin{array}{l}\text { - certification and } \\
\text { verification of } \\
\text { sustainability } \\
\text { process and } \\
\text { system } \\
\text { - Trustable } \\
\text { reporting } \\
\text { regarding } \\
\text { sustainability } \\
\text { - Reliable and } \\
\text { efficient sanction } \\
\text { in case of } \\
\text { contravention }\end{array}$ \\
\hline
\end{tabular}

Figure 1. The list of aspects

\section{Discussion}

As described in this article, Corporate Sustainability has reached Top-Management attention and high level organizational implementation within global enterprises.

This leads to the conclusion that Corporate Sustainability aspects are also having considerable influence within a strategic site selection of international group companies. Those Corporate Sustainability aspects should be implemented into the set of criteria for site selection in practical business live as well as in scholarship.

Example 1:

A potential site is in a country with a high rate of corruption. Within this country it would hardly be possible to receive a planning permission for a production area or an order from a customer without these illegality payments. It is not really imaginable, that an individually liable member of board will face this legal risk in connection with this site, having in mind that his corporate group is having a Corporate Sustainability reporting caring for transparency regarding those items internationally.

Example 2:

There are two comparable alternatives for a new business site to open up new markets.

One is a country with a supplier base having e.g. no workers' representation, bad standards on occupational safety, high environmental pollution and in many cases child labor. The other country has a west orientated legislation with clear regulations regarding workers' representation, environment protection, standards on occupational safety and prohibition of child labor. In case all the other conditions are comparable, the management of the group will surely select the country, where sustainability aspects can be followed along the entire supply chain.

With these examples it can easily be seen, that Corporate Sustainability aspects are having serious influence on the decisions regarding sites, also those aspects are no hard facts, which could be quantified in money with direct influence on cost. 
A company with an effective Corporate Sustainability organization will surely secure all the above mentioned sustainability aspects inside the company. But regarding a site selection process there are external factors, which cannot be ruled by internal guidelines. These external influences have to be Sustainability aspects concerning site, country or regional selection.

Following these arguments, the additional site selection criteria to be added to the general list of selection criteria with regard to Corporate Sustainability are the aspects shown in the table above with the concrete focus on the availability of a supplier base, able to follow those listed sustainability criteria.

Another cluster where a sustainability criteria is to be added is, "governmental influence" with the aspect of "working against corruption", expressly, if it is possible to receive permissions (e.g., for buying land, construction and imports) without any kind of corruption payments.

\section{Summary}

In scientific literature there are already existing several industrial location theories and doctrines including the in each case connected classification and sets of criteria for site selection. The new publications subdivide location criteria into Hard and Soft facts in meaning of criteria which can be quantified in money and are having direct influence on cost and qualitative criteria which are having indirect effects on the company and their employees. But in no publication the today very important criteria within industry "Compliance" is reflected. By conviction of the author, these aspects regarding compliance, deducted within this article are important for the site selection process of industrial companies. They should be considered for site selection process and added within scientific literature as well as for business applications.

\section{Acknowledgments}

Diplom Kaufmann Christian Schneider, born 1967 in Schweinfurt, Germany. Since 2009 PhD. Student at the Slovak University of Technology in Bratislava, Institute of Industrial Engineering and Management, Trnava, Slovak Republic. I kindly thank my PhD. adviser, prof. doc. Ing. František Horňák, PhD., for giving me the opportunity to do this $\mathrm{PhD}$. study, for all the helpful critical discussions and especially for revising this article.

\section{References}

Adam, D. (1997). Produktionsmanagement (9th ed.). Gabler.

Behrens, K. (1971). Allgemeine Standortbestimmungslehre (2nd ed.). Westdeutscher Verlag Opladen.

Büter, C. (2010). Internationale Unternehmensführung. Oldenbourg Wissenschnschaftsverlag GmbH.

Dauth, W. (2010). IAB and University of Erlangen-Nuremberg. IAB Discussion Paper, 07/2010, Nürnberg.

Fasse, M. (1999). Johann Heinrich von Thünen: "Der isolierte Staat" (24th ed.).

Grabow, B. (2005). Weiche Standortfaktoren in Theorie und Empirie - ein Überblick. Thießen, Cernavin, Führ, Dunker \& Humblot, Berlin.

Grabow, B., Henkel, D., \& Hollbach-Grömig, B. (1995). Weiche Standortfaktoren. Kohlhammer, Stuttgart.

Hong, J. (June $3^{\text {rd }}$, 2013). Double-engine economy China. Retrieved from Daily.com: http://www.chinadaily.com.cn/cndy/2013-06/03/content_16557985.htm

International Monetary $\quad$ Fund. (July 2013). Retrieved from http://www.imf.org/external/pubs/ft/weo/2013/update/02/

Jones, D. Sustainability $\quad$ Indices. $\quad$ Retrieved http://www.sustainability-indices.com/sustainability-assessment/corporate-sustainability.jsp

Kulke, E. (2008). Wirtschaftsgeographie, Grundriss Allgemeine Geographie (3rd ed.). UTB, Paderborn.

Modul Wirtschaftsgeoraphie III, Weber, Punkt. Retrieved from e-geographie: www.e-geography.de/module/weber/html/intro.htm

Schaltegger, S., Hörisch, J., Windolph, S. E., \& Harms, D. (2012). CORPORATE SUSTAINABILITY BAROMETER 2012. Center for Sustainability Management e.V., Leuphana Universität Lüneburg.

Schaltegger, S., Herzig, C., Kleiber, O., Klinke, T., \& Müller, J. (2007). Nachhaltigkeitsmanagement in Unternehmen. Bundesministerium für Umwelt, Naturschutz und Reaktorsicherheit.

Schätzl, L. (2003). Wirtschaftsgeographie 1. Theorie. (9th ed.). Schöningh, UTB, Paderborn.

Schröder, K. (2013). Nachhaltigkeit in globalen Lieferketten (1st ed.). econsense - Forum Nachhaltige Entwicklung der Deutschen Wirtschaft e. V., Berlin. 
Smith, D. M. (1981). Industrial Location, An Economic Geographical Analysis (2nd ed.). John Wiley \& Sons, Inc.

Thießen, F. (2005). Weiche Standortfaktoren - die fünf Sichtweisen. Thießen, Cernavin, Führ, Dunker \& Humblot, Berlin.

Ulrich van Suntum. (1980). Die Thüng'schen Ringe. Wirtschaftswissenschaftliches Studium, WiSt, 9th. year, Journal 8, 1980, p. 383.

UN Global Compact-10 Principles. $\quad$ Retrieved from http://www.unglobalcompact.org/aboutthegc/thetenprinciples/principle10.html

United Nations General Assembly. (2005). 2005 World Summit Outcome, Resolution A/60/1, adopted by the General Assembly on 15 September 2005.

United Nations General Assembly. (March 20, 1987). Report of the World Commission on Environment and Development: Our Common Future; Transmitted to the General Assembly as an Annex to document A/42/427 - Development and International Co-operation: Environment; Our Common Future, Chapter 2: Towards Sustainable Development; Paragraph 1". United Nations General Assembly. Retrieved, March 1st, 2010 .

United Nations publication. (1987). Sales No. E.73.II.A.14 and corrigendum, chap. I.

Weber, A. (1909). Über den Standort der Industie, Reine Theorie des Standorts (1st ed.). Thübingen.

Wöhe, G. (2002). Einführung in die Allgemeine Betriebswirtschaftslehre (21st ed.). München.

http://de.wikipedia.org/wiki/Global_Compact

http://de.wikipedia.org/wiki/Johann_Heinrich_von_Thüngen

http://www.nachhaltigkeit.rw.uni-erlangen.de/

http://www.wirtschaftslexikon24.net/d/standorttheorie/standorttheorie.htm

\section{Copyrights}

Copyright for this article is retained by the author, with first publication rights granted to the journal.

This is an open-access article distributed under the terms and conditions of the Creative Commons Attribution license (http://creativecommons.org/licenses/by/3.0/). 